\title{
THE HAROLD FLAKSER COLLECTION
}

\author{
BY VINCENT H. PELOTE
}

Mr. Pelote is Librarian of the Institute of Jazz Studies, Rutgers University

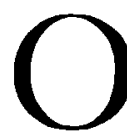

N OCTOBER 20, 1986 the Institute of Jazz Studies (IJS) officially received its single most significant acquisition since coming under the auspices of Rutgers University: the private collection of Harold Flakser. This important addition further enhances the IJS's international reputation as the most comprehensive library for jazz research.

\section{The $I J S^{\mathrm{s}}$}

The Institute of Jazz Studies (IJS), located on the first floor of Bradley Hall at Rutgers-Newark, is the largest jazz archive in the world. It was founded in 1952 by the late Dr. Marshall Stearns, a professor of medieval English literature at Hunter College and author of two essential jazz books. ${ }^{2}$ In I 966 Rutgers University was chosen as the Institute's permanent academic home. The collection, which has since grown considerably, contains over 90,000 sound recordings, more than 4,000 books on jazz and related subjects, and extensive holdings in jazz periodicals from throughout the world. In addition there are also vertical files on individual musicians and topics, a photograph collection, sheet music (including big band arrangements, music scores, etc.) and memorabilia. Some of the latter are on display at IJS.

The IJS film collection consists of excerpts from feature films featuring jazz artists (e.g., out-takes from "Last of the Blue Devils") and various shorts and television clips. The IJS is also in the process of increasing its holdings in videocassettes on jazz.

Jazz Research

Until fairly recent times, the bulk of writing and research in the jazz field was done by dedicated amateur scholars. While they contributed greatly to the fields of discography and historical and biographical docu-

\footnotetext{
'Marie Griffin, "The Institute of Jazz Studies: A Unique Resource," The Journal of the Rutgers University Libraries, vol. 43, no. 2 (December 198 I), pp. 83-10 I.

= Marshall W. Stearns, The Story of Jazz (New York: Oxford University Press, 1956) and Jazz Dance: The Story of American Vernacular Dance, coauthored with Jean Stearns (New York: Macmillan, 1968).
} 


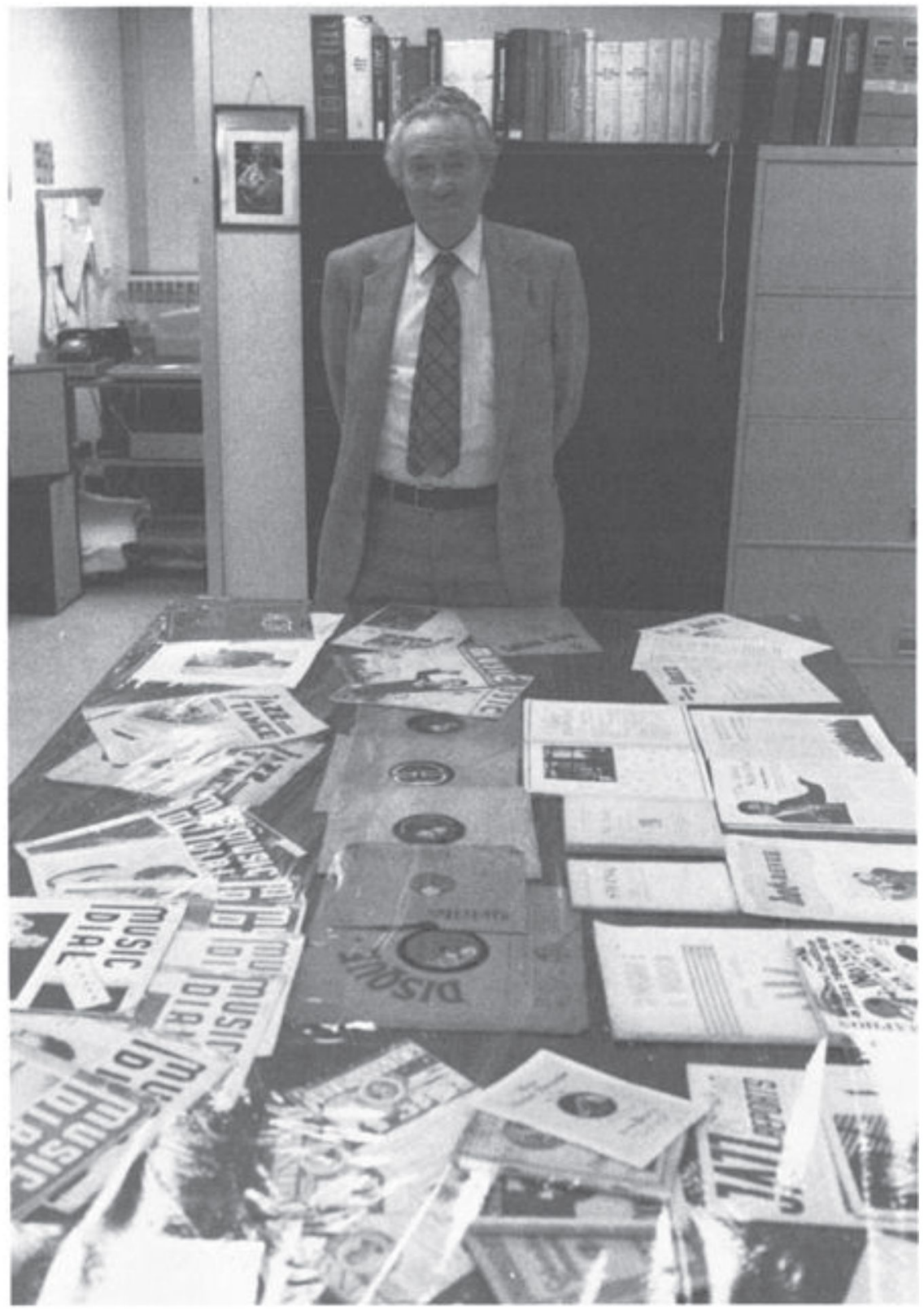

Harold Flakser at the Institute of Jazz Studies with a display of some of his rare records and periodicals. 
mentation, scholarly musicological analysis was largely neglected. Instead, what passed for jazz scholarship was often little more than unsubstantiated opinions, myths, and hero-worship by well-meaning fans of the music. The renowned composer, conductor and music scholar Gunther Schuller states in his ground-breaking book Early Jazz: "That this [body of writing on jazz] was allowed to pass for scholarship and serious analysis is attributable not only to the humble, socially 'unacceptable' origin of jazz, but also to the widely-held notion that a music improvised by selftaught, often musically illiterate musicians did not warrant genuine musicological research." 3 Those viewpoints persisted into the I960s, when some major universities began to consider jazz as an acceptable field of study. But as jazz began to be accorded some serious academic attention, researchers soon discovered that the information they needed for the most part was not to be found in the traditional types of scholarly journals. Rather, essential sources were often ephemeral publications, many of them of European origin, or long defunct American periodicals. The systematic acquisition of such materials was the province of a handful of private collectors such as Harold Flakser rather than of academic institutions and libraries. With the addition of the Harold Flakser collection, IJS has moved much closer to realizing its goal of consolidating all the research tools pertaining to jazz and making them accessible to scholars and researchers.

\section{Harold Flakser}

Harold Flakser is a recognized jazz researcher and authority on the history of jazz periodicals who knows facts and details about the publishing history of each of the hundreds of titles in his collection. He has been a contributor to almost all major jazz discographies and is also an authority on the international film industry as well.

Born February I 9, 1925 in Brooklyn, New York, Flakser has been a serious collector for more than 45 years. He started collecting in I 939, when he first discovered recordings by the Quintette of the Hot Club of France, a pioneering European jazz group (consisting of three guitars, a violin and a string bass) which included the legendary gypsy guitarist Django Reinhardt. In that same year he also discovered the Commodore Music Shop (located at 144 East 42nd Street in Manhattan), founded by record producer Milt Gabler and patronized by musicians and jazz fans

\footnotetext{
3 Gunther Schuller, Early Jazz: Its Roots and Musical Development (New York: Oxford University Press, I968), p. vii.
} 


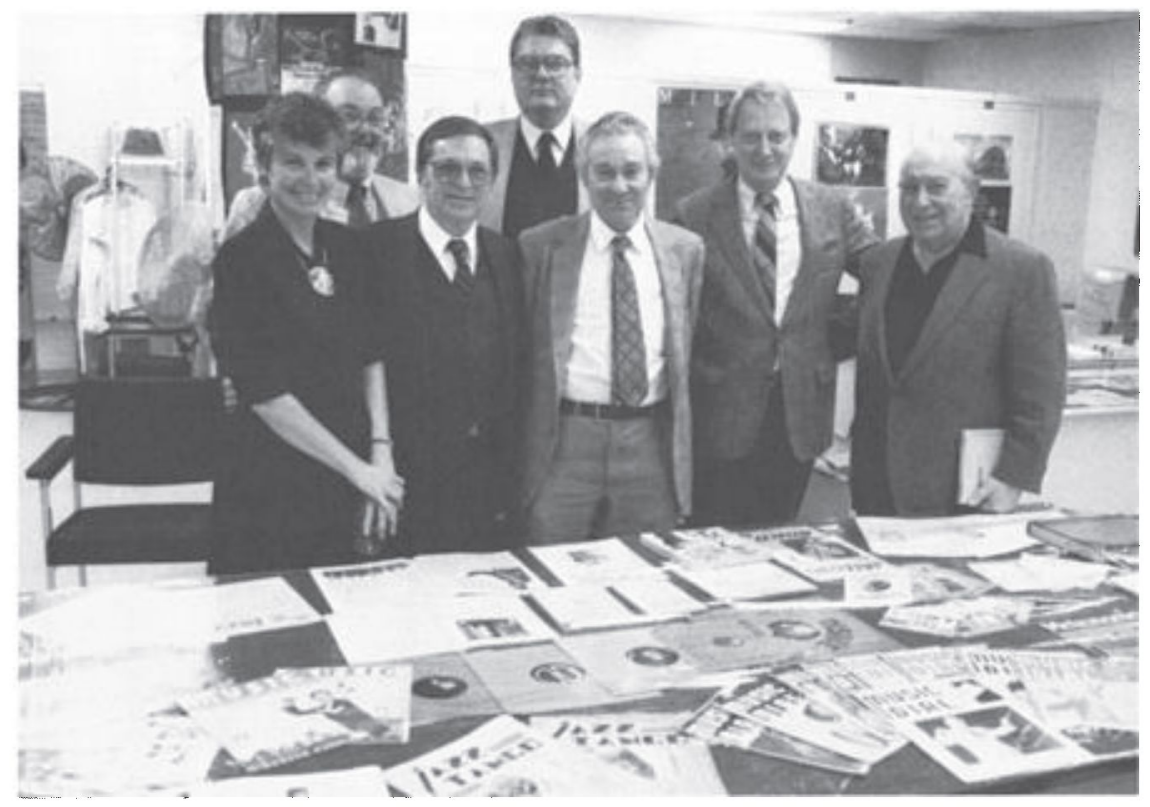

(left to right): Caroline Coughlin (Director of Libraries, Drew Univ.); David Cayer (Associate Vice President for Academic Affairs and Co-Editor, Annual Revierw of Jazz Studies); William Weinberg (Chairman, IJS Advisory Board); Charles Nanry (Prof. of Industrial Relations, Co-Editor Annual Review of Jazz Studies); Harold Flakser; Dan Morgenstern (Director, IJS); Milt Gabler (Founder and President, Commodore Records)

Ed Berger

alike. Of the many labels carried by this store, Flakser became particularly enthralled with the French Swing label, the first record label dedicated exclusively to jazz. Founded in early I 937 by Charles Delaunay and Hugues Panassie, Swing primarily recorded either visiting Black American jazz stars or expatriates (e.g., Dicky Wells, Freddy Johnson, Bill Coleman, etc.). Flakser, using Charles Delaunay's Hot Discography ${ }^{4}$ as a guide, concentrated on acquiring the French Swing label recordings. Meanwhile, his tastes expanded to collecting jazz recorded in other countries.

The periodicals which form the pièce de resistance of the Flakser collec-

4 Charles Delaunay, Hot Discography, edited by Hot Jazz (Paris: 1936). 
tion were originally an adjunct to his record collecting activities but soon became the main emphasis. A great deal of material was acquired through trading with other collectors and some was purchased. According to Flakser, the periodicals that cost him the most were the Argentinian jazz periodicals, primarily Sincopa y Ritmo.

Flakser's Brooklyn apartment soon became a mecca for international jazz researchers as it contained treasures not available anywhere else. The list of scholars, authors, and musicians who visited Flakser reads like a Who's Who in jazz research. Among the visitors were the late Walter C. Allen and Morroe Berger, who wrote definitive bio-discographies of bandleader/arranger/pianist Fletcher Henderson ${ }^{5}$ and alto saxophonist/ bandleader/arranger Benny Carter. ${ }^{6}$ Robert Pernet, author of Jazz in Little Belgium, expressed his gratitude in this dedication: "My best thanks are for the one and only Harold Flakser (Brooklyn, USA). The greatest collector of the world, who knows better than everyone the story of the European pre-war Jazz scene. In hoping that one day he could find the time to write a book on the subject, since long overdue." 7 The musicians who visited Flakser, mostly to listen to recordings not readily available anywhere else, include Danish bandleader Kai Ewans, American expatriate bandleaders Sam Wooding and Willie Lewis, reed player Gene Sedric, trumpeter Bill Coleman, and many more.

Flakser's reasons for parting with the collection he so laboriously compiled were many, but his realization of his own mortality was undoubtedly the most important. He feared that upon his demise his collection would be "tossed out in the trash." Flakser, a longtime personal friend of Dan Morgenstern, the director of the Institute of Jazz Studies, was well aware of Rutgers' unique and specialized library. Flakser knew that if he sold his collection to the IJS, it would be treated with the proper care and respect and be made accessible to researchers in ways he was not always able to do. Another consideration had to do with what Flakser himself called the IJS's "physical propinquity." Having his collection located close to his Brooklyn home and easily accessible by public transportation weighed heavily in favor of IJS as the new and permanent home of the Harold Flakser collection.

5 Walter C. Allen, Hendersonia: The Music of Fletcher Henderson and his Musicians (Highland Park, N.J.: i 973).

${ }^{6}$ Morroe Berger, Edward Berger, James Patrick, Benny Carter: A Life in American Music (Metuchen, N.J.: Scarecrow Press, I982).

7 Robert Pernet, Jazz in Little Belgium (Bruxelles, Belgium: 1966), p. 9. 


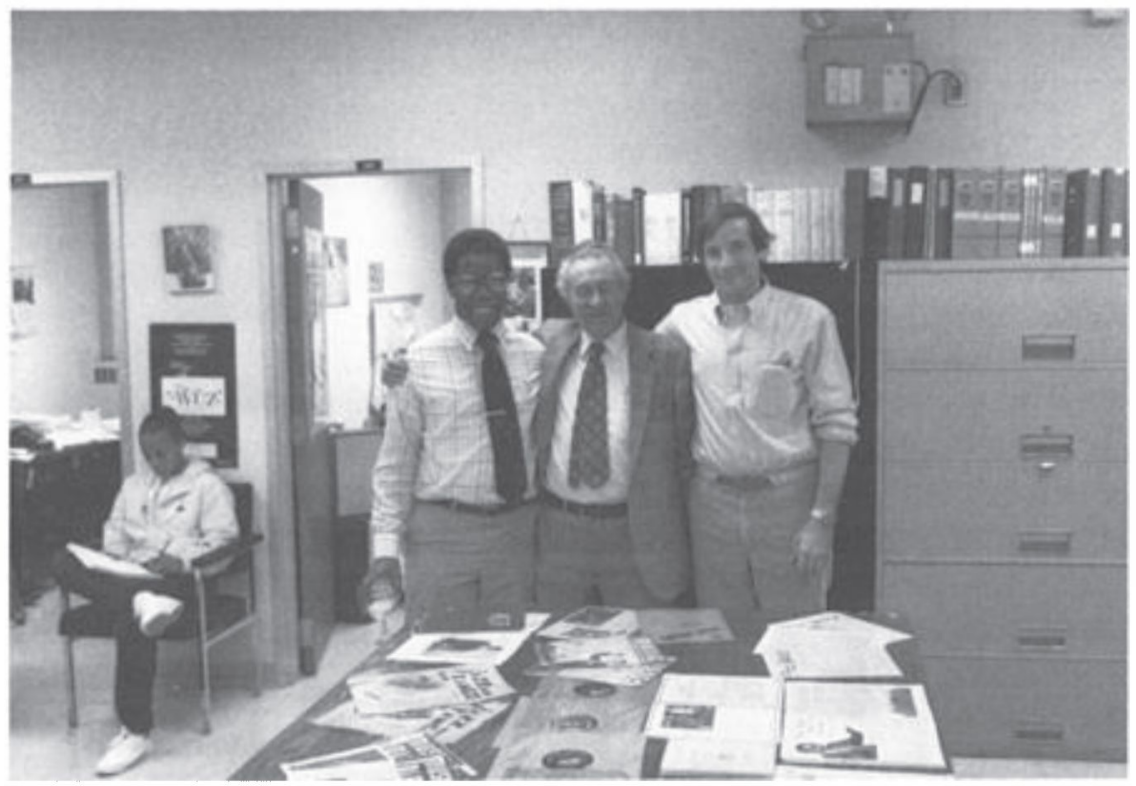

Flakser with Vincent Pelote, Institute of Jazz Studies Librarian (left), and Edward Berger, Institute of Jazz Studies Assistant Director (right).

Ed Berger

\section{The Collection}

Of the several components of the Harold Flakser collection, the periodicals are the most important. The IJS now has the finest collection of jazz periodicals anywhere, including the national libraries of the European countries where many of the pioneer periodicals originated. The more than 300 titles include many rare, one-of-a-kind items, dating from the 1920 s to the present. Included in the collection are complete runs of many major publications, such as the British Melody Maker, which began publishing in 1926. The French Revue de Jazz (1929-30) is one of the many rarities in the collection. Only eight issues were published, of which Flakser acquired five (issues two, three, and nine are missing). This periodical is so rare that even the Bibliothèque Nationale in Paris was unaware of its existence. Another great rarity is the American Music Dial, a fascinating magazine published between 1943 and 1945 by a group of musicians in Harlem. Flakser was flabbergasted when he discovered that 
he had more issues of it than the Schomburg Center For Research in Black Culture in Harlem. Other items of particular importance are the clandestine jazz bulletins published during the Nazi occupation of France.

The second major component of the Flakser collection is its holding of 3,000 books on jazz and related subjects that originate from all over the world. A large proportion are obscure foreign titles from the I 920 and ' 30 , and are often nearly unique.

The Flakser record collection is the third major component. It consists of more than 4,000 $78 \mathrm{rpm}$ discs and a small grouping of LPs. The $78 \mathrm{~s}$ represent a very specialized and extremely rare selection of foreign issues recorded between the late I 9 I OS and mid-I 940 s, primarily by the many American musicians then active in Europe. There are also one-of-a-kind items, including several unissued test pressings.

Rounding out the collection are several thousand record catalogs (including many rare European items), pamphlets, ephemera, and assorted memorabilia (e.g., letters written by gypsy guitarist Django Reinhardt).

\section{Preservation of Flakser Periodicals}

The IJS is in the process of microfilming and/or binding many of the periodicals in the Flakser collection. Over 200 volumes of periodicals have been bound, so far. Microfilming is being undertaken for periodicals judged too fragile for binding. Among the latter group are the early years of Down Beat (IJS is one of only a small group of libraries worldwide to have a complete run from the magazine's inception in 1934), as well as the British Melody Maker (IJS may well have the only copies in the U.S. of the early years of this important publication). 